\title{
Family education in a comparative legal perspective
}

\author{
Sayana Bairovna Balkhaeva*, Andrey Evgenievich Pomazansky, and Fatima Valerievna \\ Tsomartova \\ Institute of Legislation and Comparative Law under the Government of the Russian Federation, \\ Moscow, Russia
}

\begin{abstract}
Due to its specific character, family education is not the main direction of development for either foreign or domestic educational systems. However, the transition from the educational paradigm of an industrial society to the educational paradigm of a post-industrial society leads to an inevitable change in the goals of education and upbringing, their motives, forms, methods, etc. In modern society, family education makes it possible to provide qualitatively new opportunities for the socialization of the individual, due to the receipt of individualized, free education that ensures a person's self-realization. In addition, family education may be preferable to other forms of education in the context of the exponential growth of information and communication technologies, which made it possible to predict its development in the future. Alternative forms of education, including elements of distance and family education were in great demand in connection with the COVID-19 coronavirus infection pandemic. All the above actualizes the problems of family education, including the issues of its legal regulation. The research aims to study the experience of legal regulation of obtaining family education in foreign countries with the aim of its reception in Russian legislation. To achieve this goal, the article considered several areas that are of fundamental importance for the normal functioning of the family education such as the implementation of the parents' right to choose the form of education, the control over the quality of education received, setting the requirements for compliance with established educational programs and standards, financial support and other material participation of the state in providing education received in the family form, as well as sanctions for violation of the norms of educational legislation on family education. The article concludes that family education is not a fundamental right, but qualifies as an acceptable form of education. The organization of family education in different countries proceeds from the balance of interests of the child, the parents, and the society as the main principle of the legal regulation of family education.
\end{abstract}

Keywords: family education, distance education, right to education, comparative law, children's rights

\footnotetext{
*Corresponding author: sayanabb@gmail.com
} 


\section{Introduction}

The legal status of family education in the context of international legal regulation is ambiguous. Thus, its supporters emphasize their adherence to international legal norms and find a justification for their position in Art. 28 of the 1989 Convention on the Rights of the Child, which proclaims the child's right to education, "not the right to go to school" [1]. Art. 2 of Protocol No. 1 to the 1950 Convention for the Protection of Human Rights and Fundamental Freedoms, which states that "no one can be denied in receiving education," declares education as a fundamental right of the child. However, according to the researchers, it can be interpreted as allowing the use of a variety of methods and forms of education: "the state must respect the parents' right to provide such education that corresponds to their religious and philosophical convictions" [2]. Opponents of family education interpret the norms of the same Convention on the Rights of the Child in exactly the opposite way: Art. 29 restricts the right of parents and others to education in the family since it requires that all education be aimed at fostering respect for human rights and fundamental freedoms, as well as the principles proclaimed in the Charter of the United Nations and a list of other specific values and ideals [3].

The legal position of the European Court of Human Rights regarding family education was formulated while considering the possibility of its legislative prohibition through the prism of the right to education, enshrined in Art. 2 of Protocol No. 1 to the Convention for the Protection of Human Rights and Fundamental Freedoms [4]. The applicants in the case are parents belonging to the Christian community who consider it unacceptable for their children to receive an education in public and private schools in Germany because they provide sex education, study fairy tales, and the level of physical and mental violence among students increases. In this regard, they educate their children at home. Parents, on behalf of their children, submitted a request for a religious exemption from compulsory attendance at primary school. The school administration denied this request. This refusal was confirmed by the German courts. Overall, compulsory education regulations in Germany are regarded as the most restrictive in Europe [5].

The European Court of Human Rights, when deciding on the legislative ban on family education in Germany, recalled that parents cannot be denied the right to give their children an education that is consistent with their convictions. At the same time, "the right to education, by its nature, needs state regulation, while the state enjoys a certain margin of appreciation in establishing and interpreting the rules for its educational system" [6]. The European Court accepted the conclusion of the German courts that homeschooling is less effective than attending school for achieving the goals of integration into society and gaining social experience, eventual and within the scope of the state's discretion in the field of human rights and freedoms. Thus, the court confirmed the legitimacy of such a prohibition, referring to the fact that it is about the fundamental right of children to education, and not the right of parents to provide it themselves.

Summing up what has been said about the legal status of family education, it should be concluded that in the internationally accepted legal system of coordinates, family education is not a fundamental right, but qualifies as an acceptable form of education [7-9].

\section{Methods}

In most developed countries, family education is seen as an alternative to private and public schools. In addition, in the context of the rapid development of information technologies, this form of education is recognized as the most appropriate for the educational needs of families living in remote rural areas, as well as families temporarily living abroad [10].

The organization of public relations in connection with the family education of children 
in foreign countries is carried out within the framework of [11]:

a) the norms of educational legislation on private schools;

b) the norms of educational legislation on the equivalence of different types of education;

c) the independent institution of educational law.

\section{Results and discussion}

A comparative legal analysis of the foreign countries' educational legislation norms made it possible to identify the following effective mechanisms for regulating relations in the field of family education.

\subsection{Consolidation of the parents' right to choose the form of education}

Family education, as a rule, is based on the legislatively enshrined right of parents to choose the form of education for their children.

The highest legal guarantees of such a right, constitutional and legal, are established in Denmark: parents or guardians who independently educate their children or children taken under guardianship, following the standards of general primary education, cannot be forced to send their children or children, taken under guardianship, to primary schools (Art. 76 of the Danish Constitution).

The 2000 French Education Code states that compulsory education can be obtained either in schools (public or private), or in the family, or by any other person of the parents' choice (Art. L. 131-1).

Article 7 of the UK Education Act 1996 obliges parents to ensure their school-age children receive a rhythmic, effective education that is appropriate for their age, physical and mental abilities, and other special educational needs, whether through regular school attendance or otherwise. "The right to homeschooling, therefore, is conditional on the fulfillment of this obligation by the parents" [1], and the statutory opportunity to receive education "in any other way" is interpreted as the parents" right to choose whether to educate their child at school or home.

In Norway, the child's right to education is also realized through the choice of a public school, a private school, or education in a family by the parents.

In the United States, the parents' right to choose the form of education was established in the course of precedent practice, which developed as follows.

The Meyer v. Nebraska (1923) and Pierce v. Society of Sisters (1925) cases are the historic decisions that enshrined the right of parents to direct the education of their children. In 1972 the US Supreme Court (Wisconsin v. Yoder (1972)) recognized the right to home education for religious reasons. In these decisions, the Supreme Court has unequivocally expressed its position that the state has the right to "establish reasonable rules for the control of basic education". Thus, the state "has the legal right to require home education to meet certain requirements" [12].

The general conclusion of experts on the case-law of the United States in the field of family education is as follows: the right of parents to homeschooling their children is established in decisions of the US Supreme Court so clearly that any legislative attempts to prohibit it will be completely suppressed on constitutional and legal grounds [13]. Family education is now legal in all fifty states of the United States. In 37 of them, certain norms related to home education have been adopted and are in effect.

At the same time, the concept of deregulation prevails in the legal ordering of relations in the field of family education in the United States, one of the illustrations of which is the very typical position that "even though there are more children studying in families in California 
than in any other state, there is still no legislation on homeschooling, and what is more, there is no need for it" [14].

\subsection{Establishing the grounds for choosing a family form of education}

The parents' right to choose the family form of education for their children, as a rule, is limited by the need to justify such a choice.

For example, in the UK, parents can choose to study at home for various reasons. At the same time, it is emphasized that for the purposes of state control the compliance of the provided home education with the educational needs of the child is primary, as opposed to the reasons for choosing this form of education by the parents [15].

\subsection{Public registration of children and control over the quality of education received in the family}

The institutions of public accounting and control are an important element of the family education legal regulation system. They have established themselves as effective and are widely implemented even in countries with the most liberal state attitude towards family education.

French law prescribes two types of public control over home education. The first type of control is an adequate examination, which is carried out by the mayor's office, starting from the first year and then every two years to a) establish the reasons for homeschooling, which are stated by the persons responsible for the child, b) establishing the correspondence of the education provided to children with their state of health, and c) checking the living conditions in the family.

To exercise the right to provide home education in the UK, parents do not have to go through any registration or approval procedures with local authorities. As amended by the 1996 Education Act and the 2006 Education and Inspections Act, local governments are required to identify and keep records of all school-age children living in the area and not receiving education. However, according to special explanations of this norm by the Ministry of Education, children receiving education at home are not subject to such registration.

In the United States, it is common for parents to report their child's performance to the district schooling department once or twice a year. Public authorities practically do not control either the content of educational programs, or the organization of the learning process, or the choice of study aids. The state takes control of an educational institution only when it does not ensure compliance with the country's key national interests (such as patriotic education, etc.).

\subsection{Standards for the qualifications of parents}

Foreign legislation establishes liberal standards for the qualifications of parents teaching children in the family, including those in terms of the presence or absence of educational qualification.

In the UK, parents have the right to involve private tutors and others in the education of their children. Involving others does not relieve parents of responsibility for the education of their children. 


\subsection{Requirements for compliance with established educational programs, standards, etc.}

Since it is important to ensure freedom in learning, as well as an individual, creative approach of family education as the immanent qualities of this form of education, such requirements are, for the most part, the most general.

In Norway, family education should be comparable to education in public schools. The freedom in the choice of teaching methods is normatively established, but the goals of education are legally defined for both school and home education. In New York State, there are compulsory subjects legally required for family education.

\subsection{Financial and other material participation of the state in the provision of education received in the family form}

One of the main trends in the development of the regulation of family education in developed foreign countries is the consolidation of legal mechanisms for financial and other kinds of participation of the state and local government in the provision of family education.

In the UK, parents are fully financially responsible for the family education of their children, including the cost of any public exams. In some cases, a combination of the parent's activities and local authorities within the framework of home education can fully cover the educational needs of the child. Currently on the agenda of the UK Department of Education [16] is the issue of wider participation of local authorities in financing home education, particularly to cover the costs of passing final exams, for college preparation, etc.

\subsection{Sanctions for violating the norms of educational legislation on family education}

The fulfillment of legal obligations in the field of family education is ensured by the established sanctions for violating the relevant provisions of educational legislation (ranging from a fine to forced transfer to study in public or private schools, or even deprivation of parental rights).

According to the Education Act of Great Britain (part 3 of Art. 437), home education can be forcibly replaced by school education if two conditions are met simultaneously: a) the parents to whom the notification was sent cannot confirm that the child receives a proper education; b) local authorities consider it appropriate for the child to attend school. In this case, the local authorities shall serve on the parent an order (referred to in this Act as a "school attendance order"), requiring him to cause the child to become a registered pupil at a school named in the order. The school attendance order is perceived as a last resort; only after all reasonable steps have been taken to resolve the situation.

\section{Conclusion}

Summarizing the issues related to the legal status of family education in foreign countries under consideration, it is noted that through the prism of international law family education is not a fundamental right, but it qualifies as an acceptable form of education. The organization of family education in different countries proceeds from the balance of interests of the child, the parents, and the society as the main principle of the legal regulation of family education. A comparative legal analysis of the norms of educational legislation of foreign countries made it possible to identify mechanisms for regulating relations in the field of family education that have proved to be effective and are being introduced even in countries with the most liberal attitude of the state towards family education. Those include securing 
the right of parents to choose the form of education, establishing the grounds for choosing family forms of education, public registration of children and control over the quality of education received in the family, fairly liberal standards for the qualifications of parents, requirements for compliance with established educational programs, standards, etc., financial and other material participation of the state in providing education received in the family form, sanctions for violation of the norms of educational legislation on family education.

\section{References}

1. D. Monk, Child and Family Law Quart. 21(2), 155-184 (2009)

2. S.V. Yankevich, N.V. Knyaginina, J. Rus. Law 9, 92 (2018)

3. D.M. Smolin, Int. Law Rev. 20, 81-110 (2006)

4. European Court of Human Rights, 35504/03, Court (Fifth Section), Decision KONRAD v. GERMANY dated 11/09/2006. Accessed on: July 19, 2021. [Online]. Available:

https://www.stradalex.com/en/sl_src_publ_jur_int/search/jur_eur_cedh_en_2006091

5. Ch. Beck, Home Education - New Political Tension? The case of Northern Europe, in XX Conference "Towards the end of educational systems? Europe in a world perspective”, July, London, 2002 (London, 2002)

6. F.V. Tsomartova, Poluchenie obrazovaniya vne obrazovatelnykh organizatsii: problemy pravovogo regulirovaniya [Obtaining education outside educational institutions: problems of legal regulation], in N.V. Putilo, N.S. Volkova (eds.), Educational legislation of Russia. New development milestone (IZiSP, Moscow, 2015)

7. H. Achilles, SchulVerwaltung HRS, 5, 154-157 (2003)

8. C. Rinio, Zeitschrift für Jugendrecht, 88(6), 221-237 (2001)

9. W. Habermalz, Recht der Jugend und des Bildungswesens, 49(2), 2001

10. A.M. Novikov, Postindustrialnoe obrazovanie [Post-industrial education] (Agves Publ. House, Moscow, 2008)

11. J. McMullen, SC Law Rev. 54(1), 75-100 (2002)

12. R. Kunzman, Theory and Res. Edu. 7(3), 311-330 (2009)

13. B.V. Nikolaev, Constit. and Munic. Law 2, 37 (2008)

14. Ch. Olsen, Brigham Young Univ. Edu. and Law J. 2, 399-423 (2009)

15. M.N. Kasatkin, Bul. Moscow Univ. Min. Int. Aff. Rus. 4, 31-32 (2015)

16. Current position on home education and SEN funding. Accessed on: July 19, 2021. [Online]. Available: https://webarchive.nationalarchives.gov.uk/20110910013724/https://www.education.g ov.uk/schools/pupilsupport/parents/involvement/homeeducation/a0061362/currentposition-on-home-education-and-sen-funding 